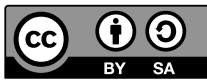

DOI: https://doi.org/10.4312/keria.21.2.163-167

Janez Orešnik

\title{
Prvi prevodi Homerja v islandščino (1820-1855)
}

Po naselitvi nekaterih obrežij otoka Islandije so izobraženi (najbrž predvsem politični oporečniki iz vrst norveškega plemstva) zapolnjevali vsakoletna temna polletja (»večno noč«) s pisanjem (takrat na pergament). Ovekovečili so mitološka besedila (največ je bilo pesmi), ki so jih bile germanske jezikovne skupnosti ohranile iz pragermanskega obdobja, nato začeli zapisovati kroniko (zgodovino) svojih družin in druge vsebine (oboje največkrat imenovano »saga«). Pomudili se bomo samo pri staroislandskem izvirnem pesništvu, ki se je prav razbohotilo v več smereh, pri čemer je ohranilo in dalje razvijalo izključno aliteracijski verz, prav tako podedovan iz pragermanskega obdobja (zato vsaj delno izpričan v vseh starih germanskih jezikovnih skupnostih; zlasti znana je staroangleška pesnitev Bēowulf (okoli 3182 verzov)). A zunaj Islandije so aliteracijsko poezijo kmalu zamenjale bolj južne oblike pesniškega izražanja.

Opisati aliteracijsko pesništvo v islandski izvedbi je zapleteno. Omejujem se na najnujnejše in v tej zvezi tudi na prvotno. Vse besede jezika so naglašene na prvem zlogu (še dandanes); prim. naše = Gregorčičevo védra víšnjevost (višáv). Verz je sestavljen iz po dveh stičnih polverzov, navadno imenovanih a in b. V polverzu a se vsebinsko izraziti besedi začenjata $z$ enakim soglasnikom. V polverzu b pa se le ena vsebinsko izrazita beseda začenja $z$ enakim soglasnikom kot aliterirajoči besedi v polverzu a. Zapleti (tu niso razloženi) so v sklopu $s+p / t / k$ in pri samoglasnikih. V resnici je bil sistem že v srednjem veku precej širši (prvi učbenik islandskega aliteracijskega pesništva je iz okoli 1270!) in je v rabi še vedno, celo v priložnostnih stihih, ki jih pisci nekrologov spesnijo za svoj zapis o nedavno preminuli osebi.

Od druge polovice 17. stoletja so vznikali tudi islandski prevodi tujih stvaritev v vezani besedi, zlasti tistih s protestantsko usmeritvijo. Zgodaj so se lotili Miltonove epopeje Paradise Lost (»Izgubljeni raj «). Blankverz te angleške pesnitve so islandski prevajalci odklanjali, dopuščali so samo aliteracijskega. 
Pri tem se je skotila nerodna zadrega, saj je bil Miltonov stih precej daljši od aliteracijskega. V slednjem je bila razdalja med enakimi aliteracijami (dve v okviru a-ja in ena v okviru b-ja) le majhna, da se je moglo zaznavati ujemanje med njimi, tudi kadar se je pesem podajala ustno. Miltonu so bili kos tako, da so vsak njegov verz razdelili na dva ali še več svojih polverzov. Zato je islandski prevod Miltona precej daljši od izvirnika. Podobno so domači stihotvorci ravnali, ko so iz nemščine prelivali zajetni Klopstockov ep Der Messias (»Mesija $)$, in v drugih primerih.

Po vrsti uspešnih prepesnitev so se čutili dolžne, da domačim bralcem približajo največjega pesnika sploh, Homerja.

Skromno vednost o Troji so hranili Islandčani že od druge polovice 13 . stoletja. Vir jim je bil islandski prevod nekega latinskega besedila (širom znanega, a nenatančnega in kratkega) o stari Troji; prevod so filologi pozneje naslovili Trójumanna saga (»Saga o prebivalcih Troje«).

O prevajanju Homerja se je gotovo največ razpravljalo na edini tedanji gimnaziji Islandije. (V tisti hiši je zdaj sedež predsednika države, blizu glavnega mesta Reykjavíka.) Pri pouku sta bila v ospredju klasična jezika, in ravnatelj gimnazije je bil prav takrat (v Prešernovem času!) po stroki teolog in klasični filolog Sveinbjörn Egilsson (1791-1852).

Za poglavitno tehnično oviro so šteli Homerjev heksameter. Tega so se Islandčani kot povsem tujega otepali. Z druge strani jim je bil tudi aliteracijski verz za nadvse cenjeni Iliado in Odisejo nekako okoren. Zadrega se je izšla v odločitev, naj se epa prestavita v nevezano besedo.

Častno nalogo je prvi prevzel ravnatelj gimnazije. Najprej je deset let pripravljal prevod Odiseje v prozo, a se še pred koncem tega opravila rajši posvetil Iliadi. Poročilo (iz peresa dijaka in pozneje odličnega islandskega zgodovinarja Melsteða) pravi, da je po gimnaziji zavelo silno navdušenje, ko so se bili dijaki seznanili s še nekončanim rokopisom in res pretreseni ugotavljali, da je prevod enakovreden izvirniku. Islandsko pesniško izrazje (kovalo se je bilo nenehno že od srednjega veka) je premoglo ustreznike za domala vse Homerjevo besedje (za manjkajoče slovarske enote pa so iz domačih sestavin zlahka tvorili nove, zlasti zloženke), in ta okoliščina je Islandčane navdala s silnim ponosom. Prevod z naslovom Ilíonskviða (»Iliada«) je izšel kot knjiga v Reykjavíku leta1855. (Glej na sliki 1 začetek prvega speva v tem prvotisku.)

Zaradi kakovosti prevoda kot prevoda in zaradi sijajne islandščine v njem se Iliada v prozi šteje za prelomnico v islandski književnosti, ne najmanj zato, ker je bilo med dijaki tistega časa več kasneje izvrstnih pesnikov, in ti so se v svojih stvaritvah v marsikaterem pogledu naslanjali na prvi prevod Iliade in sploh na prevode obeh epov.

Po prozni Iliadi se je ravnatelj Sveinbjörn Egilsson takoj vnovič posvetil Odiseji in jo v prozni obliki postopoma (med leti 1829 in 1840) objavljal v knjižicah z naslovom Odyseifskviða. 
Po dodatnem premisleku so spoznali, da veliko spoštovanje do Homerja in njegove besedne umetnosti vendarle ne izključuje aliteracijskega verza. Zato je ravnatelj Sveinbjörn Egilsson po daljšem premoru začel prevajati Iliado še v vezano besedo, a je začeto prepesnitev dokončal in 1856 (pod naslovom Ilíonskvœði) v Reykjavíku objavil njegov najmlajši sin Benedikt (Sveinbjarnarson) Gröndal (yngri) (1826-1907). Gröndal je v stihe prevedel tudi Odisejo; prevod pod naslovom Odyseifskvæði je izšel v letih 1853-54 v Kopenhagnu. (Glej začetek prvega speva na sliki 2.)

DODATEK

\section{ILÍONS - KVIDA. FYRSTI PÁTTUR.}

Wrè pú, gyđja, um hina fársfullu heiptarreiừi Akkils Peleifssonar, pá er olli Akkeum ótölulegra mannrauna, og sendi til Hadesar-heims margar hraustar kappa-sálir, en lèt sjálfa bá veròa hüdun og alls konar hræfuglum a herfángi, eptir bað að peir höfơu eitt sinn deilt og skilið osáttir, herkonúmgarinn Atreifsson og hinn ágæti Akkilles. Svo vary fyrirætlan Seifs framgeing.

Hverr guðanna var pað pá, er hleypti peim saman, til að eigast við̌ orðadeilu? . Pað var sonur Letóar og Seifs. Hann var reiour konúnginum, og lèt koma skæð̃a sótt í herbúðirnar, svo fólkið dó; var pà fyrir bá sök, að Atreifsson hafơi svivirt hofgoðann Krýses: pví Krýses hafði komið til hinna fljótu skipa Akkea, og æetlaði að leysa út dóttur ${ }^{1}$ sína; hafơi hann með sèr 6grynni fjár til útlausnar, og hèlt upp kórónu hins lángskeyta

i) Hún hìt Astynoma. 


\section{ILIONS-KVADI.}

\section{FYRSTA KVI円A.}

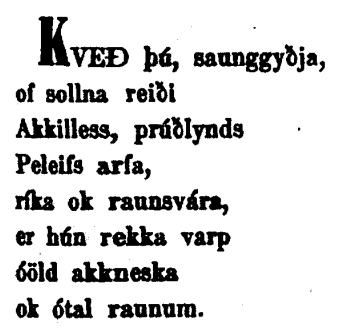

2. Hverfol hán margra hetja öndum styrkra at stöbrum stillis draugheima, en fur hauka hratt ok hrøvarga, of lagt lagti, lopotinga kind.

3. Svá mundu rát rémmast ragna fortur, fro buf or fyrst folknárúngar tvistir upp rlsu, ok rómu hơfu: allvaldr albj6ras Atreifs nifbr, ok at ognum wir Ałkilleifr.

p. I, 1-14.
4. Hverr mundi etja ölingum peim guð at grimmri geira róstu? Pat var sveigvaldr, Seifi borinn, ok Letóar ljuffr arfi.

5. Relor vard hann roosi, ok 1 resis llibi sott rakti svára, en sjotir dou; bvi at Atreifs arfi úvirban harol Krýses, helgan hörga gæti.

6. Gekł hann at gánghrö̀um graebis-vögnum, ok leysa vildi ina ljosu mey; fluttl fjöld meilya fagra, 6mældra, dýrrar lausnargjald dóttur sinnar.

7. Hafoi i höndum höfubsveiga Tororings Apollons

Slika 2: Začetek verznega prevoda Iliade

\section{POVZETEK}

V prvi polovici 18. stoletja je aliteracijski verz, to edino sredstvo islandskega domačega in prevedenega pesništva, preprečeval rabo heksametrov, celo Homerjevih. Odločili so se, da prestavijo oba epa $\mathrm{v}$ prozo, po ponovnem preudarku pa tudi $\mathrm{v}$ aliteracijski verz. Odgovorne naloge se je lotil Sveinbjörn Egilsson, tedanji ravnatelj edine gimnazije na Islandskem. Pripravil je prozno različico obeh epov in se posvetil prepesnjenju Iliade v verze; a končanje dela mu je preprečila smrt. Kot naslednji prevajalec Homerja je ravnateljev najmlajši sin Gröndal dokončal očetovo verzno Iliado in pripravil v verzih tudi celotno Odisejo. 


\section{SUMMARY \\ Early translations of Homer into Icelandic (1820-1855)}

Before the translation of Homer into Icelandic had begun, the alliterative verse, this only vehicle of Icelandic domestic and translated poetry, precluded the option of using any hexametres, not even Homer's. The solution adopted for Homer was to recast his two epic poems in prose and, after a reconsideration, in alliterative verse as well. The responsible task was undertaken by Sveinbjörn Egilsson, then the rector of the only secondary school on Iceland. He prepared the prose versions of both epic poems, and began to translate the Iliad into verse; however, he died before concluding his work. As the next translator of Homer, the rector's youngest son Gröndal completed his father's verse Iliad as well as recast, in verse, the complete Odyssey. 